\title{
GEOGRAPHICAL VARIATION IN LARVAL HOST-PLANT USE BY Heliconius erato (LEPIDOPTERA: NYMPHALIDAE) AND CONSEQUENCES FOR ADULT LIFE HISTORY
}

\author{
RODRIGUES, D. ${ }^{1}$ and MOREIRA, G. R. P. ${ }^{2}$ \\ ${ }^{1}$ Programa de Pós-graduação em Ecologia, Instituto de Biociências, UFRGS, Av. Bento Gonçalves, 9500, \\ Prédio 43422, CEP 91501-970, Porto Alegre, RS, Brazil, e-mail: drodrig@ufrgs.br \\ ${ }^{2}$ Departamento de Zoologia, Instituto de Biociências, UFRGS, Av. Bento Gonçalves, 9500, Prédio 43435, \\ CEP 91501-970, Porto Alegre, RS, Brazil, e-mail: gilson.moreira@ufrgs.br \\ Correspondence to: Dr. Gilson R. P. Moreira, UFRGS, Instituto de Biociências, Departamento de Zoologia, \\ Av. Bento Gonçalves, 9500, Prédio 43435, CEP 91501-970, Porto Alegre, RS, Brazil, \\ e-mail: gilson.moreira@ufrgs.brou drodrig@ufrgs.br \\ Received May 2, 2001 - Accepted July 12, 2001 - Distributed May 31, 2002
}

(With 6 figures)

\begin{abstract}
Adult body size, one of the most important life-history components, varies strongly within and between Heliconius erato phyllis (Lepidoptera: Nymphalidae) populations. This study determines if this variation is caused by geographical changes in host-plant used by the larval stage, whose reproductive parameters are influenced by female body size, with estimates of the corresponding heritability. The variation in adult body size was determined together with a survey of passion vine species (Passifloraceae) used by the larvae in seven localities in Rio Grande do Sul State: three located in the urban area of Porto Alegre and Triunfo Counties, two within Eucalyptus plantations (Barba Negra Forest, Barra do Ribeiro County, and Águas Belas Experimental Station - Viamão County), one in a Myrtaceae Forest (Itapuã State Park - Itapuã County) and one in the Atlantic Rain Forest (Maquiné Experimental Station - Maquiné County). Effects of female body size on fecundity, egg size and egg viability were determined in an outdoor insectary. Size heritability was estimated by rearing in the laboratory offspring of individuals maintained in an insectary. The data showed that adults from populations where larvae feed only upon Passiflora suberosa are smaller than those that feed on Passiflora misera. The larvae prefer $P$. misera even when the dominant passion vine in a given place is $P$. suberosa. Fecundity increases linearly with the increase in size of females, but there is no size effect on egg size or viability. Size heritability is null for the adult size range occurring in the field. Thus, the geographical variation of $H$. erato phyllis adult size is primarily determined by the type, corresponding availability and quality of host-plants used by the larval stage. Within the natural size range of $H$. erato phyllis, the variation related to this caracter is not genetically based, thus being part of $H$. erato phyllis phenotypic plasticity.
\end{abstract}

Key words: body size, passion vines, heliconian butterflies, reproductive success, heritability.

\section{RESUMO}

\section{Variação espacial no uso de plantas hospedeiras e conseqüências na história de vida de Heliconius erato (Lepidoptera: Nymphalidae)}

Os adultos de Heliconius erato phyllis (Lepidoptera: Nymphalidae) variam acentuadamente em relação ao tamanho corporal. Neste trabalho, avalia-se a hipótese de que tal variação se deva em parte a diferenças qualitativas do recurso alimentar da fase larval (passifloráceas) existentes em campo. Em adição, identifica-se como a performance reprodutiva das fêmeas é influenciada pelo tamanho, sendo também estimada a herdabilidade dessa característica. Determina-se a variação espacial do tamanho corporal em sete populações de H. erato phyllis do Estado do Rio Grande do Sul (RS), situadas em 
ambientes urbanos (3), matas de Eucalyptus (2), mata de Mirtáceas (1) e Mata Atlântica (1), e relacionase tal variação ao recurso larval utilizado. Em insetário, quantifica-se a influência do tamanho das fêmeas nos parâmetros fecundidade, viabilidade e tamanho do ovo. A herdabilidade do tamanho foi estimada por intermédio da criação, em laboratório, da prole de indivíduos mantidos em insetário. Os adultos das populações cujas larvas utilizaram unicamente Passiflora suberosa foram significativamente menores em relação às que utilizaram Passiflora misera. As larvas foram encontradas preponderantemente sobre $P$. misera, mesmo quando P. suberosa foi a espécie predominante em um dado local. Dentre os parâmetros de performance reprodutiva estudados, apenas a fecundidade teve relação direta com o tamanho. A estimativa da herdabilidade para o tamanho foi zero. Assim, confirma-se a importância do recurso alimentar larval na determinação da variabilidade do tamanho dos adultos. Tal variação é parte da plasticidade fenotípica das populações naturais de $H$. erato, sendo a contribuição genotípica pouco expressiva neste caso.

Palavras-chave: tamanho corporal, maracujás, heliconíneos, sucesso reprodutivo, herdabilidade.

\section{INTRODUCTION}

Body size is recognized as one of the most important life-history components for many animal species (e.g., Peters, 1983; LaBarbera, 1989; Roff, 1992; Stearns, 1992). Several studies focusing on insects (e.g., Honek, 1993; Klingenberg \& Spence, 1997; Nylin \& Gotthard, 1998; but see Leather, 1988), including Lepidoptera (e.g., Labine, 1968; Dunlap-Pianka, 1979; Elgar \& Pierce, 1988; but see Boggs, 1986), have pointed out the existence of a positive correlation between body size and fecundity. In nymphalid butterflies, Dunlap-Pianka (1979) showed that there is a positive correlation between body size and fecundity in Heliconius charitonia (Linnaeus), and between body size and oviposition rate in $H$. erato (Linnaeus). In this study, we examine the effects of larval host-plant use on adult size in $H$. erato phyllis (Fabricius), and the corresponding consequences for female reproductive success.

Heliconiine butterflies are closely associated with their larval host-plants, the passion vines (Passifloraceae) (for reviews, see Benson et al., 1976; Brown, 1981; Turner, 1981; Gilbert, 1991). Larvae of some species, as for example those of $H$. erato, feed upon a wide range of passion vine species. Physical and chemical properties, such as leaf toughness, concentration of nutrients and secondary metabolities, vary both intra- and interspecifically in such host-plants (Benson et al., 1976; Smiley, 1978; Brown, 1979; Brown, 1981). Variation in host plant properties is expected to produce changes in the adult life history of $H$. erato, as has been demonstrated for many herbivorous insects (see Derr et al., 1981; Scriber \&
Slansky, 1981; Slansky, 1993; Bernays \& Chapman, 1994; Fernandes, 1994).

Both larval host plant species and plant part consumed influence larval development of $H$. erato phyllis. Tests perfomed in an enclosed insectary demonstrated that ovipositing females prefer P. misera over P. suberosa (S. M. Kerpel, UFRGS, unpublished data), and Menna-Barrreto \& Araújo (1985) and Périco (1995) showed that pupae of Heliconius erato phyllis are heavier when larvae feed on Passiflora misera Humboldt, Bonpland et Kunth as compared to those reared on Passiflora suberosa Linnaeus. In addition, studies carried out in our laboratory demonstrated that larvae prefer feeding on $P$. misera over $P$. suberosa, and that feeding preference can not be induced in the larval stage (S. M. Kerpel, UFRGS, unpublished data). $H$. erato females preferentially oviposit on intact, apical Passiflora shoots compared to damaged ones (Mugrabi-Oliveira \& Moreira, 1996b). On a given intact Passiflora shoot, a newly hatched larva typically selects the youngest tissue for feeding, which allows it to achieve greater survivorship and development rate compared to those that feed on mature leaves, but not necessarily a larger pupal size (Rodrigues \& Moreira, 1999).

H. erato larvae have a solitary feeding habit and are cannibalistic (Benson et al., 1976), supposedly an adaptation to limiting plant tissue (Gilbert, 1991; Brower, 1997). In Viamão Municipality, Rio Grande do Sul State, a substantial number of $H$. erato eggs are laid on plants whose total leaf area is less than what is needed to complete larval development (Mugrabi-Oliveira \& Moreira, 1996a). In addition, Rodrigues (1999) found that food shortage during the fifth instar has profound effects 
on survivorship and size attained in the adult stage. It is unknown whether adult size influences reproductive performance, which is also investigated in this study.

In $H$. erato, it has been documented that adult size varies both within and between populations (Benson et al., 1976) (Fig. 1). Given that host plant use by larvae can affect adult size, we examine here the hypothesis that geographical variation in $H$. erato adult size is caused at least in part by host-plant shifts among populations in the field. To test for this hypothesis, we documented $H$. erato phyllis adult size for different passion vine species used by the larval stage in several localities in Rio Grande do Sul State. We also examined the importance of size on female life history characteristics, by evaluating fecundity, egg size and viability, and determined size heritability, to evaluate whether the variation in adult size observed for $H$. erato is genetically based or simply phenotypic plasticity.

\section{MATERIAL AND METHODS}

\section{Geographical variation in host-plant use and adult size}

The possibility of a correlation between larval host-plant use and adult size was examined in seven areas in Rio Grande do Sul State: 1) Parque Estadual de Itapuã (30²3'S; 5055' W), predominantly a Myrtaceae forest; 2) Estação Experimental de Maquiné (293' S; 50²' 'W), part of the Atlantic Rain Forest; 3) Estação Experimental de Águas Belas (30 $\left.05^{\circ} \mathrm{S} ; 5^{\circ} 02^{\prime} \mathrm{W}\right)$ and 4) Horto Florestal Barba Negra (30 $23^{\prime} \mathrm{S}$; $\left.51^{\circ} 12^{\prime} \mathrm{W}\right)$, both old $E u$ calyptus plantations; and three urban areas: 5) Fundação Zoobotânica and 6) Instituto de Pesquisas Hidráulicas/UFRGS (City of Porto Alegre $30^{\circ} 05^{\prime} \mathrm{S}$; 51 $1^{\circ} 10^{\prime} \mathrm{W}$ ), and 7) Parque COPESUL (295' S; 51 $\left.{ }^{\circ} 43^{\prime} \mathrm{W}\right)$. Sampling was done from April 22 to May 22, 1998, during the heliconian population peak (Saalfeld \& Araújo, 1981). For each locality, the sampling area consisted of a 250$\mathrm{m}$ long, 3-m wide trail section.

For each locality, trails were sampled once, during early morning (samples lasted at most three hours). All Passiflora individuals in the trail were surveyed, counting branches with intact apical buds (apical meristem, leaf primordia and unopened leaves), and $H$. erato phyllis immatures per branch.

Forewing length is considered to be a good predictor of body size for Lepidoptera in general (Miller, 1977; Haukioja, 1993), being highly correlated with pupal size in $H$. erato phyllis (Rodrigues, 1999). Thus, concomitantly with examination of plants, adults found along the trail were captured with an insect net and their forewing length (base to apex) measured to the nearest 0.05 $\mathrm{mm}$ with a pair of calipers. Measured butterflies were numbered on the forewing red patch with a felt-tipped pen, and then released.

\section{Female reproductive performance in relation to size}

Examination of reproductive performance was based on $23 \mathrm{H}$. erato phyllis females (wing length varying from 29.55 to $40.45 \mathrm{~mm}$ ) captured at the Fundação Zoobotânica and the Instituto de Pesquisas Hidráulicas/UFRGS. They were individually kept in outdoor insectaries of the Zoology Department of the Universidade Federal do Rio Grande do Sul, following methods described in Dunlap-Pianka (1979). Adults were fed daily with a mixture of commercially available honeybee pollen (AGA®), honey (AGA®) and distilled water (ratio 2:1:7) (details in Mugrabi-Oliveira \& Moreira, 1996a).

In each insectary three potted Passiflora suberosa Linnaeus plants were available for oviposition. They were inspected daily for presence of eggs, which were removed from the plants by using a fine, moist brush, and individually placed in Petri dishes, lined with moist filter paper. Eggs were kept in a large laboratory chamber (14 hours of light: 10 hours of darkness; $25 \pm 1^{\circ} \mathrm{C}$ ), and checked daily for newly hatched larvae.

Females were monitored for daily oviposition rate during a time interval that varied from 10 to 20 days (average 18.4 days per female). Estimates of egg volume were based on the first eggs laid by females, varying from 15 to 30 per female. By using a stereomicroscope equiped with a micrometric scale, egg height and maximum diameter were measured, and then used to estimate egg volume. In average, 25.95 eggs were used to estimate the egg volume produced by a given female. Egg viability corresponded to the larval hatching rate of undamaged eggs.

\section{Size heritability}

Size heritability was determined by crossing newly emerged females $(\mathrm{n}=10)$, reared from adults collected at the Fundação Zoobotânica and the Instituto de Pesquisas Hidráulicas, with males collected from the same places. This procedure was justified by the fact that $H$. erato females are 
monogamous, and in most cases mate during or immediately after emergence. In contrast, males achieve sexual maturity later in life (Alexander, 1961). Paired males and females (parents $=$ P) had similar forewing length, which varied from 33.02 to $39.67 \mathrm{~mm}$ per pair. Mating pairs were maintained in individual outdoor insectaries, following the methodology described above. The procedure for collection and incubation of eggs was as described above. Newly hatched larvae (offspring $=\mathrm{F}_{1}$ ) were individually transferred to branches of $P$. suberosa in water-filled, plastic bottles. The branches came from potted plants that were transplanted at an early stage from the Estação de Águas Belas population (Mugrabi-Oliveira \& Moreira, 1996a), and maintained under cultivation in outdoor enclosures. Food was offered ad libitum, with P. suberosa branches replaced whenever necessary. Plants were covered with a fine mesh cloth, and kept in the laboratory chamber until adult emergence. The forewing length of freshly emerged adults (the 30 first offspring of each couple) was also measured with calipers as described above.

\section{Statistical analysis}

Adult size frequency distributions for each area were evaluated for normality and homocedasticity of variances through Kolmogorov-Smirnov and Bartlett tests. When analyses of variance were significant, differences among localities were compared by using Tukey's multiple comparison tests. Size effects were evaluated through regression analyses using all reproductive parameters. Heritability was estimated by regressing the average size of parents in relation to that of their offsprings, with $h^{2}$ corresponding to the slope of the resulting regression line (Falconer, 1989; Stearns, 1992; Beiguelman, 1994). Parametric and non-parametric tests followed procedures described in Sokal \& Rohlf (1981) and Conover (1980), respectively. Unless noted measurements are given as mean $\underline{ \pm}$ standard error.

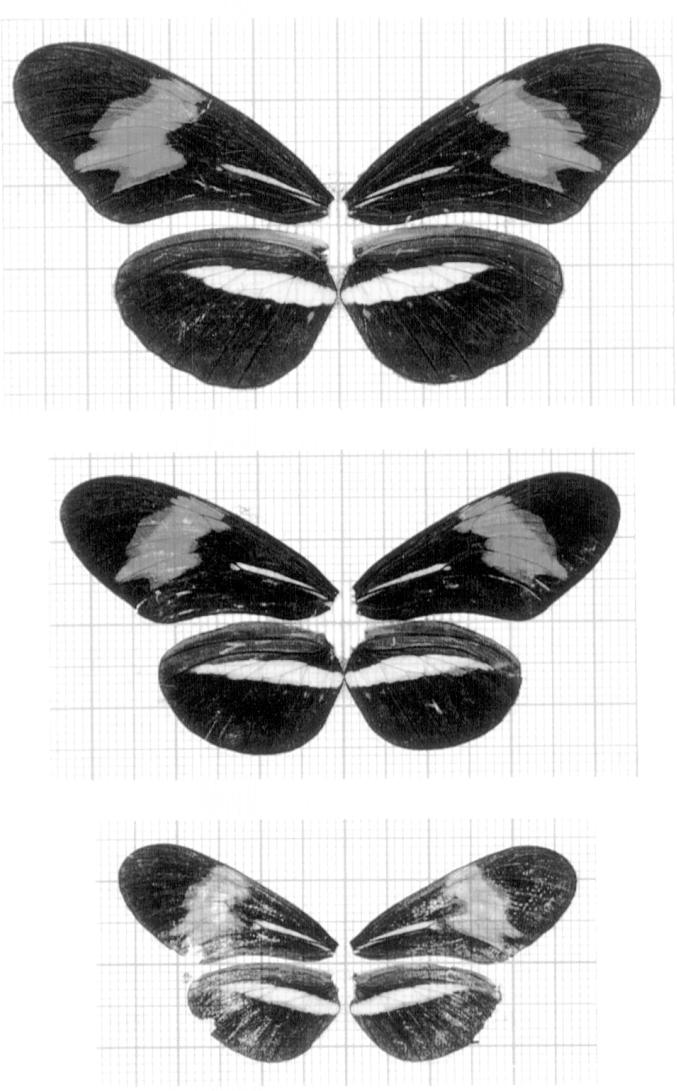

Fig. 1 - Variation in H. erato phyllis forewing length. Large squares $=0.5 \mathrm{~cm}$. 


\section{RESULTS}

\section{Geographical variation on host-plant use and} adult size

Eight passion vine species were found in the seven study sites: $P$. suberosa Linnaeus, $P$. misera Linnaeus, $P$. caerulea Linnaeus, $P$. elegans Masters,
P. alata Dryander, P. tenuifila Killip, P. actinia Hooker and P. capsularis Linnaeus (Fig. 2).

Species composition of passion vine communities varied among localities. $P$. suberosa or $P$. misera were present at all sites, with the main hostplants being used, except at Estação Experimental de Maquiné.

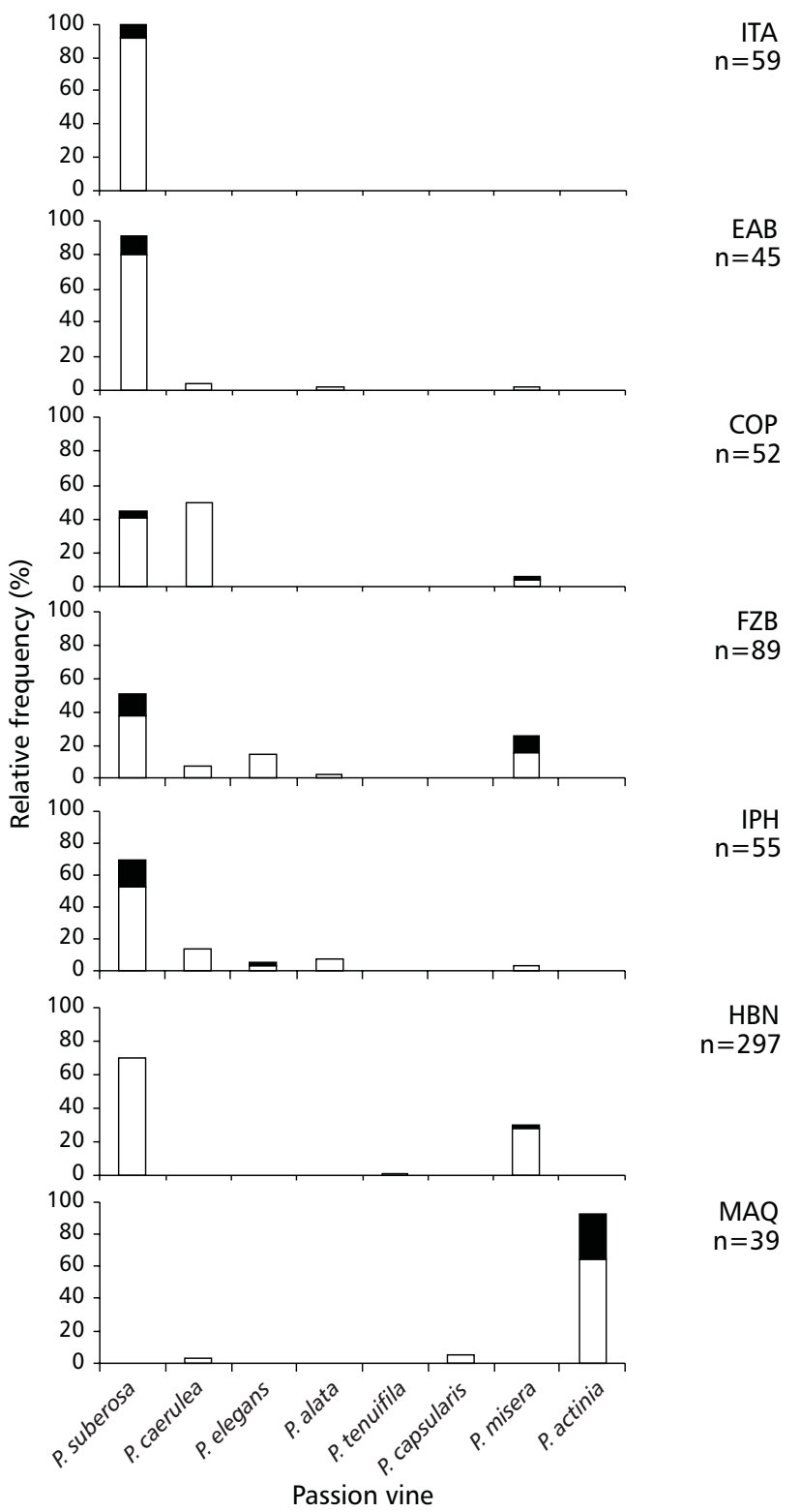

Fig. 2 - Relative abundance of passion vine species among localities. Dark portions of bars correspond to relative frequencies of shoots with immatures of $H$. erato phyllis. ITA, Parque Estadual de Itapuã; EAB, Estação Experimental de Águas Belas; COP, Parque Copesul; FZB, Fundação Zoobotânica; IPH, Instituto de Pesquisas Hidráulicas/Campus do Vale, UFRGS; HBN, Horto Florestal Barba Negra; MAQ, Estação Experimental de Maquiné. $\mathrm{n}=$ total number of passion vine shoots sampled per locality. 
At Maquiné, P. actinia was the most abundant passion vine species and the one predominatly used by the immatures of $H$. erato phyllis.

A progressive increase on $H$. erato phyllis forewing length was found in the sites, concurrent with a shift in host plant used from $P$. suberosa to $P$. misera or $P$. actinia (Figs. 2-3).

The smallest forewing lengths were in the Parque Estadual de Itapuã and Estação Experimental de Águas Belas (Fig. 3). These were the sites where P. suberosa was the most abundant and the unique host-plant species used by $H$. erato phyllis immatures (Fig. 2).

Forewing lengths were intermediate at Parque COPESUL and Fundação Zoobotânica, places where both $P$. suberosa and P. misera were used as host-plants. They were larger at Horto Florestal Barba Negra, where $P$. misera was the only hostplant used in spite of the predominance of $P$. suberosa. The largest forewing length values were found at Estação de Maquiné, where both these host-plant species were absent.

\section{Female reproductive performance in relation} to size

Daily oviposition rate increased significantly with increase in female forewing length $(F=10.217$; $\mathrm{p}<0.0048$; Fig. 4A). Minimal and maximum rates were 0.52 and 4.92 eggs, for females with forewing length of 29.55 and $38 \mathrm{~mm}$, respectively. On the average, females laid 2.28 eggs per day.

Egg viability was not correlated with female forewing length $(\mathrm{F}=0.3696, \mathrm{p}>0.55$; Fig. 4B), nor was egg volume $(\mathrm{F}=0.1521, \mathrm{p}>0.70$; Fig. 4C). Egg viability per female varied from $44 \%$ to $82.8 \%$ (average $=65.42 \%$ ), and egg volume from 0.53 to $0.88 \mathrm{~mm}^{3}$ (average $=0.8 \mathrm{~mm}^{3}$ ).

\section{Size heritability}

The slope of the regression for offspring forewing length versus that of their parents was essentially zero (slope $=-0.0115, \mathrm{~F}=0.030, \mathrm{p}=$ 0.8661; Fig. 5). Thus, the heritability $\left(\mathrm{h}^{2}\right)$ estimated for body size in $H$. erato phyllis was null. The offspring forewing length varied from 30.15 to $41.35 \mathrm{~mm}$ (average $=37.56 \mathrm{~mm} ; \mathrm{n}=294$ ).

Development time from egg to pupa for the F1 averaged $21.65 \pm 0.12$ days. There was a significant negative correlation between development time and adult size for $\mathrm{F} 1$ individuals $(\mathrm{n}=294$; $\mathrm{F}=65.475 ; \mathrm{p}<0.0001)$.

The few individuals with development time greater than 25 days emerged with greatly reduced body size (Fig. 6).

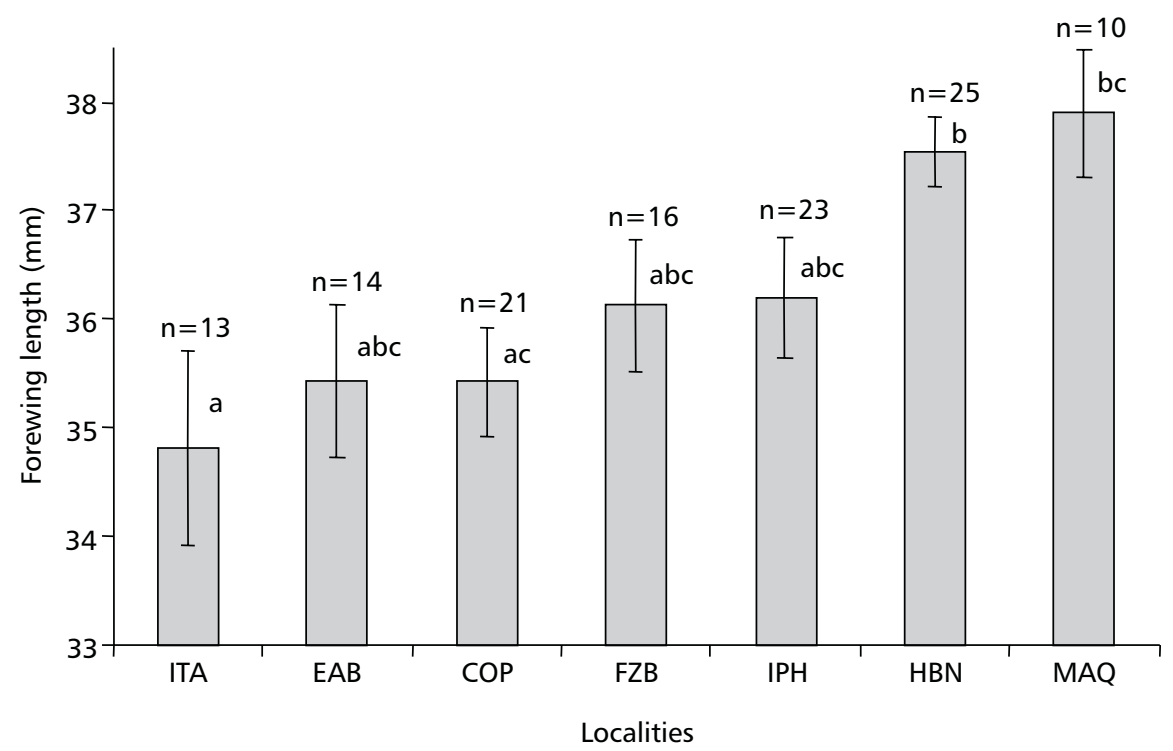

Fig. 3 - Variation in H. erato phyllis adult body size (mean \pm standard error) among localities. ITA, Parque Estadual de Itapuã; EAB, Estação Experimental de Águas Belas; COP, Parque Copesul; FZB, Fundação Zoobotânica; IPH, Instituto de Pesquisas Hidráulicas/Campus do Vale, UFRGS; HBN, Horto Florestal Barba Negra; MAQ, Estação Experimental de Maquiné. $\mathrm{n}=$ total number of adults sampled per locality. Bars followed by the same letter are not significantly different (ANOVA, alpha $=0.05$; Tukey multiple comparison tests, alpha $=0.05$ ). 

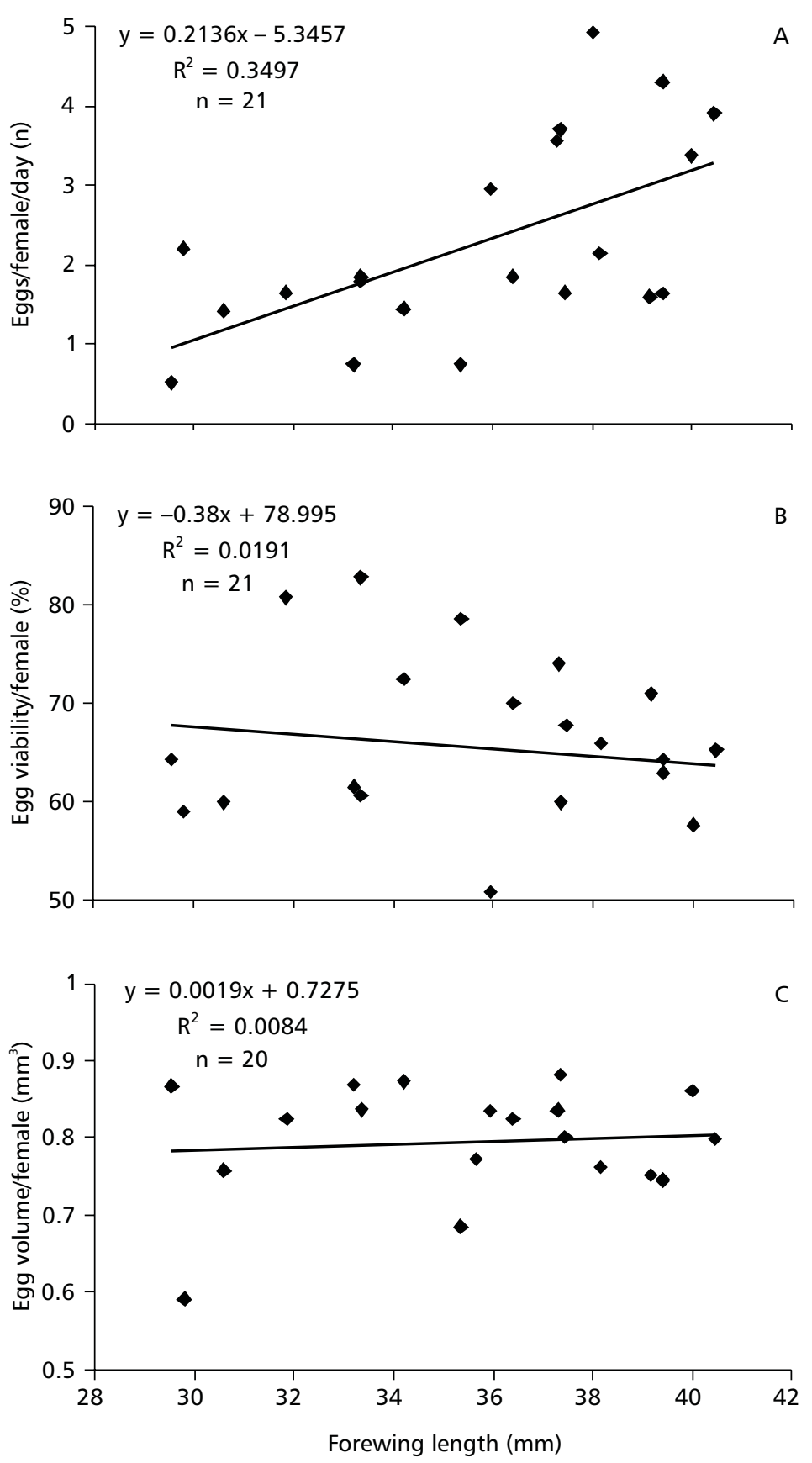

Fig. 4 - Daily oviposition rate (A), egg viability (B) and egg size (C) in relation to H. erato phyllis female body size. 


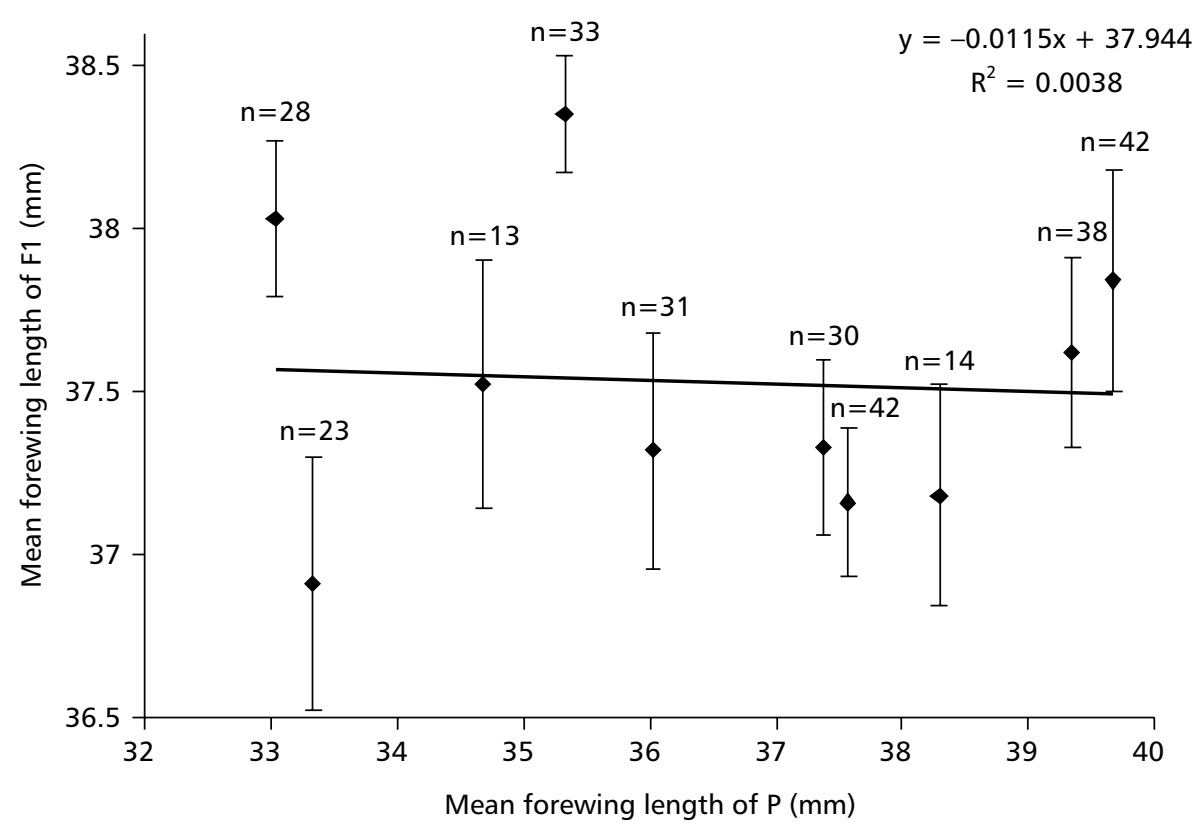

Fig. 5 - Size (mean \pm standard error) of offspring (F1) in relation to adult body size of parents (P) in H. erato phyllis. Data correspond to ten crossed pairs. $\mathrm{n}=$ number of adults obtained per cross.

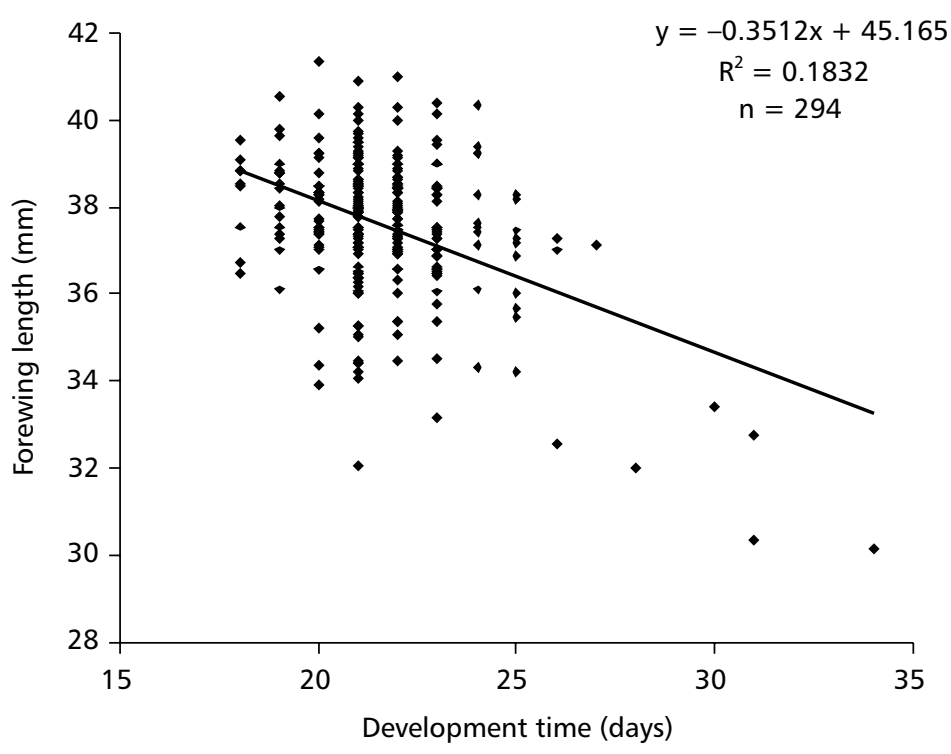

Fig. 6 - Adult size of H. erato phyllis in relation to larval and pupal development time. 


\section{DISCUSSION}

Our study indicates that $H$. erato phyllis varies in body size from place to place according to the passion vine species used as feeding resource by the larval stage. Where larvae fed basically on $P$. suberosa, adults averaged smaller than those where P. misera was used. In fact, Rodrigues (1999) demonstrated under controlled laboratory conditions that adults reared on $P$. misera are significantly larger than those reared on $P$. suberosa, independent of temperature. In one site (Horto Florestal Barba Negra), where P. misera occurred at low densities in this study, but high enough to support some larvae, $P$. suberosa was not used in spite of its greater abundance. $H$. erato phyllis females select $P$. misera over $P$. suberosa for oviposition, under field and insectary conditions, even when abundance and quality of the former species is lower (S. M. Kerpel, UFRGS, unpublished data). Nevertheless, females will lay eggs on $P$. suberosa when $P$. misera shoots are defoliated or deprived of terminal buds and those of $P$. suberosa are abundant and intact. Adults in the Horto Florestal Barba Negra are smaller during the winter, when $P$. misera is completely defoliated and P. suberosa is used as host. When immatures were reared under laboratory conditions, adults obtained from larvae that fed on $P$. misera were significantly larger than those obtained from larvae on P. suberosa (Rodrigues, 1999).

In the populations studied, we could not detect any influence on adult body size of abiotic or biotic factors other than host-plant use. The study sites are less than $100 \mathrm{~km}$ from each other and have similar altitudes. Samples were taken practically at the same time, and thus there is no indication that abiotic factors, such as temperature, could play a major role in determining the observed variation in body size. Furthermore, competition could not account for the size trend in this case, since the greatest body size values, contrary to what would be expected, were achieved when larvae fed on P. misera, the only potentially limited food resource. Parasitism is negligible in these $H$. erato phyllis populations, and there is no indication that other biotic factors, such as the existence of differential predation rates among study sites, could be an alternative explanation for the observed variation in size (G. R. P. Moreira, UFRGS, unpublished data).
The patterns of host-plant use in the field reported in this paper are in agreement with some previous studies (e.g. Romanowsky et al., 1985), however, not with other ones. Menna-Barreto \& Araujo (1985) found an oviposition preference of $H$. erato phyllis for $P$. capsularis, which was not confirmed by Périco (1995) nor was it confirmed in this study. We believe that such discrepancies can be attributed to differences in the abundance and relative quality of host-plants, a factor that was not taken into account in their studies. In general, host-plant attributes can significantly affect oviposition choices in Insecta (see Cates, 1980; Singer, 1983), including H. erato phyllis (MugrabiOliveira \& Moreira, 1996a,b). Although occurring at low densities compared to P. suberosa in the Horto Florestal Barba Negra, the population of P. misera is large enough to entirely support the $H$. erato phyllis larvae, unlike the other sites in this study.

To our knowledge, this paper presents the first documented evidence supporting the influence of geographical changes in host plant use on the variation of adult size in Lepidoptera. The effect of larval environment on adult body size in Lepidoptera was demonstrated by Cook (1961) in a pioneer study on field variation on body size among southern populations of Panaxia dominula (Arctiidae) in the British Island. In this case, wingspan strongly varied among several localities, along size with differences between males and females in some regions. When they were reared under the same conditions in the laboratory, this variation could not be detected. However, the author did not mention the corresponding larval food sources.

The existence of a positive correlation between nutrient levels of a given host-plant and body size is widely accepted for Insecta (Wickman \& Karlsson, 1989; Slansky, 1993). Within the heliconiines, this relationship has been demonstrated for Dryas iulia and Heliconius charitonia (Boggs, 1981), and for $H$. ismenius and H. melpomene (Smiley \& Wisdom, 1985). Although biochemical and physiological studies have not been done for the H. erato phyllisPassiflora system, our data suggest that $P$. misera represents a higher quality larval food resource than $P$. suberosa, yielding a larger size to adults.

We found that body size had an effect on egg production, but not on egg size or viability. The insectary data clearly demonstrate that fecundity 
increases linearly with increase in female body size. Unlike fecundity, egg size and fertility were not associated with female body size in $H$. erato phyllis. The size of eggs and that of newly hatched larvae is highly correlated in Lepidoptera (Reavey, 1992), and small first instar larvae may take a longer time to complete development (Wright \& Clarke, 1981; Happ, 1984). Inasmuch as egg size and viability were comparable for small and large $H$. erato females, our observations suggest that offspring development and competitive potential are independent of the mother's size. Wiklund et al. (1987) found that egg size may or may not be correlated with female body size depending on environmental conditions, under which the species is adapted to withstand. Independence between adapted withstand these parameters has been pointed out for several nymphalid butterflies (Boggs, 1986) and for some Diptera (Roff, 1981).

The null result for size heritability indicates low genotypic determination of this trait, which should be valid only for the size range of $H$. erato phyllis in the field. Thus in these populations, the potential size of offspring is practically the same for either small or large parents, when reared under the same conditions. The small females of $H$. erato phyllis could have a smaller reproductive apparatus, that produces and stores a lesser amount of eggs (Dunlap-Pianka, 1979); but the egg allocation in terms of size and fertility is similar to greater females. Thus, we consider the body size variation in $H$. erato phyllis as part of its high phenotypic plasticity (see Nylin \& Gotthard, 1998; Ramos \& Freitas, 1999; Correa et al., 2001). In this case, it benefits $H$. erato phyllis, by allowing this species to explore a wide range of host-plants as larval food resource, which can vary in abundance not only in space but also in time (Rodrigues, 1999). Size is a trait considered as more plastic in insects adapted to situations where larval resources fluctuate (Nylin \& Gotthard, 1998).

There are at least three reasons for explaining the absence of heritability for body size in wild H. erato phyllis populations. First, genetic additive effects for this trait may act on parent sizes outside the range included in the experiment. All mating attempts using females with forewing length below $33.35 \mathrm{~mm}$ were unsuccessful, independent of male size. This suggests the existence of a size threshold, which needs further study. Also, our methods do not exclude dominance effects, including those of maternal origin (see Falconer, 1989). In fact, the smallest offspring were obtained from one of the two smallest females in the experiment. Second, the absence of additive genetic variance may reflect the correlation of body size with other important life-history components (see Hegman \& Dingle, 1982; Roff, 1992), like larval development rate and fecundity. Third, it is possible that some degree of inbreeding had occurred among parents. This is less likely, however, since males and females used in the experiment came from different populations.

The absence of body size heritability has been also found for the bug Nezara viridula, where an intricate relation between size and larval development rate was observed (McLain, 1991). In this study, the offspring larval development rates were negatively correlated with larval size. This effect was stronger among the few larvae that had extremely reduced size. These individuals probably came from eggs, which were also smaller, since the size of eggs and that of newly hatched larvae are highly correlated in Lepidoptera (Reavey, 1992). The fact that these individuals were in low frequency in the F1 population represents another evidence for low genotypic influence on size. By being smaller since their conception, these individuals may require more time to attain the size threshold for moulting (Wright \& Clarke, 1981; Happ, 1984). The existence of a trade-off between development time and adult size has been found for many insects (e.g. Reavey \& Lawton, 1991; Klingenberg \& Spence, 1997; Nylin \& Gotthard, 1998).

Acknowledgments - We wish to thank the administration and staff of Fundação Zoobotânica, Secretaria da Agricultura/RS, Fepagro, Riocell and Copesul for allowing us to carry out the study in their parklands and reservations. Thanks are due to Aldo M. de Araújo, for literature supply and guidance on the design of heritability experiments. We are also grateful to Lenice Medeiros (Unijuí), Carla M. Penz (Milwaukee Public Museum), Márcio Zikán Cardoso (Unicamp), and to an anonymous reviewer for reading critically the manuscript. Financial support for this study came from a CAPES Scholarship (M.Sc. Thesis) granted to D. Rodrigues. This is contribution number 368 of the Zoology Department of Federal University of Rio Grande do Sul.

\section{REFERENCES}

ALEXANDER, A. J., 1961, A study of the biology and behavior of the caterpillars, pupae and emerging butterflies of the subfamily Heliconiinae in Trinidad, West Indies. Part II. Molting, and the behavior of pupae and emerging adults. Zoologica, 46: 105-123. 
BEIGUELMAN, B., 1994, Dinâmica dos genes nas famílias e nas populações. Sociedade Brasileira de Genética, Ribeirão Preto, 472p.

BENSON, W. W., BROWN, K. S. Jr. \& GILBERT, L. E., 1976, Coevolution of plants and herbivores: passion flower butterflies. Evolution, 29: 659-680.

BERNAYS, E. A. \& CHAPMAN, R. F., 1994, Host-plant selection by phythopagous insects. Chapman \& Hall, New York, 312p.

BOGGS, C. L., 1981, Nutritional and life-history determinants of resource allocation in holometabolous insects. Am. Nat., 117: 692-709.

BOGGS, C. L., 1986, Reproductive strategies of female butterflies: variation in and constraints on fecundity. Ecol. Entomol., 11: 7-15.

BROWER, A. V. Z., 1997, The evolution of ecologically important characters in Heliconius butterflies (Lepidoptera: Nymphalidae): a cladistic review. Zool. J. Linn. Soc., 119: 457-472.

BROWN, K. S. Jr., 1979, Ecologia geográfica e evolução nas florestas neotropicais. Universidade Estadual de Campinas, Campinas, 256p.

BROWN, K. S. Jr., 1981, The biology of Heliconius and related genera. Annu. Rev Entomol., 26: 427-456.

CATES, R., 1980, Feeding patterns of monophagous, oligophagous, and polyphagous insect herbivores: the effect of resource abundance and plant chemistry. Oecologia, 46: $22-31$.

CONOVER, W. J., 1980, Practical nonparametric statistics. $2^{\text {nd }}$ ed., John Wiley \& Sons, New York, 493p.

COOK, L. M., 1961, Influence of larval environment on adult size and fecundity in the moth Panaxia dominula L. Nature, 192: 282.

CORREA, C. A., IRGANG, B. E. \& MOREIRA, G. R. P., 2001, Estrutura floral das angiospermas utilizadas por Heliconius erato phyllis (Fabricius) (Lepidoptera: Nymphalidae) no Estado do Rio Grande do Sul. Iheringia, Sér. Zool., 90: 71-84.

DERR, J. A., ALDEN, B. \& DINGLE, H., 1981, Insect life histories in relation to migration, body size, and host plant array: a comparative study of Dysdercus. J. Anim. Ecol., 50: $181-193$.

DUNLAP-PIANKA, H. L., 1979, Ovarian dynamics in $\mathrm{He}$ liconius butterflies: correlations among daily oviposition rates, egg weights, and quantitative aspects of oögenesis. J. Insect. Physiol., 25: 741-749.

ELGAR, M. A. \& PIERCE, N. E., 1988, Mating success and fecundity in an ant - tended lycaenid butterfly. In: T. H. Clutton-Brock (ed.), Reproductive success: studies of individual variation in contrasting breeding systems. Chicago University Press, Chicago, pp. 59-75.

FALCONER, D. S., 1989, Introduction to quantitative genetics. $3^{\text {nd }}$ ed., Longman Scientific \& Technical, New York, 438p.

FERNANDES, G. W., 1994, Plant mechanical defenses against insect herbivory. Revta. Bras. Ent., 38: 421-433.
GILBERT, L. E., 1991, Biodiversity of a central american Heliconius community: pattern, process and problems. In: P. W. Price, T. M. Lewinsohn, G. W. Fernandes \& W. W. Benson (eds.), Plant-animal interactions: evolutionary ecology in tropical and temperate regions. John Wiley \& Sons, New York, pp. 403-427.

HAPP, G. M., 1984, Development and reproduction. In: H. E. Evans (ed.), Insect biology: a textbook of entomology. Addison-Wesley Publishing Company, Massachusetts, pp. 93-113.

HAUKIOJA, E., 1993, Effects of food and predation on population dynamics. In: N. E. Stamp \& T. M. Casey (eds.), Caterpillars: ecological and evolutionary constraints of foraging. Chapman \& Hall, New York, pp. 425-447.

HEGMANN, J. P. \& DINGLE, H., 1982, Phenotypic and genetic covariance structure in milkweed bug life history traits. In: H. Dingle \& J. P. Hegmann (eds.), Evolution and genetics of insect life histories. Springer-Verlag, New York, pp. 177-185.

HONEK, A., 1993, Intraspecific variation in body size and fecundity in insects: a general relationship. Oikos, 66: 483-492.

KLINGENBERG, C. P. \& SPENCE, J. R., 1997, On the role of body size for life-history evolution. Ecol. Entomol., 22: $55-68$.

LaBARBERA, M., 1989, Analyzing body size as a factor in ecology and evolution. Annu. Rev. Ecol. Syst., 20: $97-$ 117.

LABINE, P. A., 1968, The population biology of the butterfly, Euphydryas editha. VIII. Oviposition and its relation to patterns of oviposition in other butterflies. Evolution, 22: 799-805.

LEATHER, S. R., 1988, Size, reproductive potential and fecundity in insects: things aren't as simple as they seem. Oikos, 51: 386-389.

McLAIN, D. K., 1991, Heritability of size: a positive correlate of multiple fitness components in the southern green stink bug (Hemiptera: Pentatomidae). Ann. Entomol. Soc. Am., 84: 174-178.

MENNA-BARRETO,Y. \& ARAÚJO, A. M., 1985, Evidence for host plant preferences in Heliconius erato phyllis from southern Brazil (Nymphalidae). J. Res. Lepid., 24: 41-46.

MILLER, W. E., 1977, Wing measure as a size index in Lepidoptera: the family Olethreutidae. Ann. Entomol. Soc. Am., 70: 253-256.

MUGRABI-OLIVEIRA, E. \& MOREIRA, G. R. P., 1996a, Conspecific mimics and low host plant availability reduce egg laying by Heliconius erato phyllis (Fabricius) (Lepidoptera: Nymphalidae). Revta. Bras. Zool., 13: 929-937.

MUGRABI-OLIVEIRA, E. \& MOREIRA, G. R. P., 1996b, Size of and damage on shoots of Passiflora suberosa (Passifloraceae) influence oviposition site selection of Heliconius erato phyllis (Fabricius) (Lepidoptera: Nymphalidae). Revta. Bras. Zool., 13: 939-953.

NYLIN, S. \& GOTTHARD, K., 1998, Plasticity in life-history traits. Annu. Rev. Entomol., 43: 63-83. 
PÉRICO, E., 1995, Interação entre quatro espécies de Heliconiini (Lepidoptera: Nymphalidae) e suas plantas hospedeiras (Passifloraceae) em uma floresta secundária do Rio Grande do Sul, Brasil. Biociências, 3: 3-18.

PETERS, R. H., 1983, The ecological implications of body size. Cambridge University Press, Cambridge, 329p.

RAMOS, R. R. \& FREITAS, A. V. L., 1999, Population biology and wing color variation in Heliconius erato phyllis (Nymphalidae). J. Lepid. Soc., 53: 11-21.

REAVEY, D., 1992, Egg size, first instar behaviour and the ecology of Lepidoptera. J. Zool. Lond., 227: 277-297.

REAVEY, D. \& LAWTON, J. H., 1991, Larval contribution to fitness in leaf-eating insects. In: W. J. Bailey \& J. Ridsdill-Smith (eds.), Reproductive behaviour of insects: individuals and populations. Chapman \& Hall, London, pp. 293-329.

RODRIGUES, D., 1999, Fatores envolvidos na variação do tamanho corporal e conseqüências na história de vida de Heliconius erato phyllis (Lepidoptera: Nymphalidae). M.Sc. Thesis, Universidade Federal do Rio Grande do Sul, Porto Alegre.

RODRIGUES, D. \& MOREIRA, G. R. P., 1999, Feeding preference of Heliconius erato (Lep.: Nymphalidae) in relation to leaf age and consequences for larval performance. J. Lepid. Soc., 53: 108-113.

ROFF, D. A., 1981, On being the right size. Am. Nat., 118: 405-422.

ROFF, D. A., 1992, The evolution of life histories - theory and analysis. Chapman \& Hall, New York, 535p.

ROMANOWSKY, H. P.; GUS, R. \& ARAÚJO, A. M., 1985, Studies on the genetics and ecology of Heliconius erato (Lepid.; Nymph:). III. Population size, preadult mortality, adult resources and polymorphism in natural populations. Rev. Brasil. Biol., 45: 563-569.

SAALFELD, K. \& ARAÚJO, A. M., 1981, Studies on the genetics and ecology of Heliconius erato (Lepid.; Nymph). I. Demography of a natural population. Rev. Bras. Biol., 41: $855-860$.
SCRIBER, J. M. \& SLANSKY, F. Jr., 1981, The nutritional ecology of immature insects. Annu. Rev. Entomol., 26: 183-211.

SINGER, M. C., 1983, Determinants of multiple host use by a phytophagous insect population. Evolution, 37: 389-403.

SLANSKY, F. Jr., 1993, Nutritional ecology: the fundamental quest for nutrients. In: N. E. Stamp \& T. M. Casey (eds.), Caterpillars: ecological and evolutionary constraints of foraging. Chapman \& Hall, New York, pp. 29-91.

SMILEY, J. T., 1978, Plant chemistry and the evolution of host specificity: new evidence from Heliconius and Passiflora. Science, 201: 745-747.

SMILEY, J. T. \& WISDOM, C. S., 1985, Determinants of growth rate on chemically heterogenous host plants by specialist insects. Biochem. Syst. Ecol., 13: 305-312.

SOKAL, R. R. \& ROHLF, F. J., 1981, Biometry. $2^{\text {nd }}$ ed., W. H. Freeman and Company, New York, 859p.

STEARNS, S. C., 1992, The evolution of life histories. Oxford University Press, New York, 249p.

TURNER, J. R. G., 1981, Adaptation and evolution in Heliconius: a defense of NeoDarwinism. Ann. Rev. Ecol. Syst., 12: 99-121.

WICKMAN, P. O. \& KARLSSON, B., 1989, Abdomen size, body size and reproductive effort of insects. Oikos, 56: 209-214.

WIKLUND, C., KARLSSON, B. \& FORSBERG, J., 1987, Adaptative versus constraint explanations for egg-to-body size relationships in two butterflies families. Am. Nat., 130: $828-838$.

WRIGHT, S. \& CLARKE, K. U., 1981, Photoperiod and larval body size: integrated factors controlling onset of the moulting cycle in Heliconius melpomene. (Lepidoptera). J. Zool. Lond., 194: 143-163. 